\title{
MENINGKATKAN HASIL BELAJAR SISWA PADA MATA PELAJARAN BAHASA INDONESIA MELALUI METODE KOMPETISI DAN AKTIFITAS (KOMPAK)
}

\author{
Yayah Kustiah \\ SMP Negeri 1 Maja, Indonesia \\ yayahkustiah@gmail.com
}

\begin{abstract}
This research was conducted based on the problem of low student learning outcomes in Indonesian subjects. Various efforts can be done including by applying learning methods that can foster student interest in learning Indonesian. One method that can be used is competition and activity methods. This study aims to improve student learning outcomes by applying competition and activity methods. This research is a class action research with research subjects of VIIID grade students of SMP Negeri 1 Maja Majalengka. The results showed an increase in student learning outcomes after the competition and activity methods were applied from cycle I to cycle II. So it can be concluded that the methods of competition and activities can improve student learning outcomes in Indonesian subjects.
\end{abstract}

Keywords: learning outcomes, activities and competitions, Indonesian language

\begin{abstract}
ABSTRAK
Penelitian ini dilakukan berdasarkan permasalahan rendahnya hasil belajar siswa pada mata pelajaran Bahasa Indonesia. Berbagai upaya dapat dilakukan diantaranya dengan menerapkan metode pembelajaran yang dapat menumbuhkan minat siswa terhadap pembelajaran Bahasa Indonesia. Salah satu metode yang dapat digunakan adalah metode kompetisi dan aktivitas. Penelitian ini bertujuan untuk meningkatkan hasil belajar siswa dengan menerapkan metode kompetisi dan aktivitas. Penelitian ini merupakan penelitian tindakan kelas dengan subyek penelitian siswa kelas VIIID SMP Negeri 1 Maja Majalengka. Hasil penelitian menunjukkan adanya peningkatan hasil belajar siswa setelah diterapkan metode kompetisi dan aktivitas dari siklus I hingga siklus II. Jadi dapat disimpulkan metode kompetisi dan aktivitas dapat meningkatkan hasil belajar siswa pada mata pelajaran Bahasa Indonesia.
\end{abstract}

Kata Kunci : hasil belajar, aktivitas dan kompetisi, bahasa indonesia

Submitted Apr 26, 2020 | Revised Jun 4, 2020 | Accepted Jun 8, 2020

\section{Pendahuluan}

Pendidikan pada dasarnya adalah usaha sadar yang menumbuh kembangkan potensi sumber daya manusia peserta didik dengan cara mendorong dan memfasilitasi kegiatan belajar mereka. Pendidikan berfungsi membantu peserta didik dalam pengembangan dirinya, yaitu pengembangan semua potensi, kecakapan serta karakteristik pribadinya kearah yang positif, baik bagi dirinya maupun lingkungannya (Sukmadinata, 2004).

Bahasa Indonesia merupakan suatu mata pelajaran yang terdapat di dalam kurikulum pendidikan Indonesia, mata pelajaran bahasa Indonesia diberikan disetiap jenjang pendidikan mulai dari pendidikan dasar, bahkan sampai tingkat pendidikan perguruan tinggi masih terdapat pendidikan Bahasa Indonesia (Rohmanurmeta, 2017). Pengajaran Bahasa Indonesia mempunyai peran penting, sebab pelajaran Bahasa Indonesia bertujuan untuk mengembangkan diri dan meningkatkan kemampuan penalaran, serta kemampuan emosional dan sosial. Rendahnya hasil belajar Bahasa Indonesia adalah kegagalan siswa dalam belajar 
yang disebabkan oleh kurang efektif dalam pelaksanaan pembelajaran, apalagi dengan metode pembelajaran yang tidak variatif (Sugiyono, 2014).

Keadaan SMP dengan sistem guru kelas, tidak menutup kemungkinan banyak guru yang mengalami kesulitan dalam menggunakan model pembelajaran yang tepat untuk mencapai tujuan pembelajaran yang optimal. Karena guru dituntut untuk mengejar target materi yang cukup banyak dan harus diselesaikan pada setiap semester.

Keberhasilan pengajaran juga tergantung pada keberhasilan murid dalam proses belajar mengajar, sedangkan keerhasilan murid tidak hanya tergantung pada sarana dan prasarana pendidikan, kurikulum maupun metode. Akan tetapi guru mempunyai posisi yang sangat strategi dalam meningkatkan prestasi murid dalam penggunaan strategi pembelajaran yang tepat. Pembelajaran Bahasa Indonesia terkadang membosankan dan salah satu penyebabnya adalah karena ketidaktepatan pengajar dalam menentukan model (pendekatan) dalam pembelajaran (Ayuningrum, 2017).

Salah satu upaya yang dapat dilakukan adalah dengan melakukan inovasi di bidang pembelajaran, diantaranya menentukan metode pembelajaran yang inovatif. Metode berkaitan dengan cara-cara yang akan digunakan guru dalam menyampaikan materi pembelajaran. Sebelum melaksanakan pembelajaran, guru perlu menentukan metode yang akan digunakannya. Tentu saja, perencanaan metode pembelajaran yang akan digunakan didasarkan pada karakteristik materi, siswa, dan tujuannya. Untuk itu, tugas guru adalah paham metode serta karakteristik materi, siswa, dan tujuannya (Kurniawan, 2015). Dengan memahami kedua aspek tersebut, maka guru pun bisa menentukan metode yang tepat untuk menyampaikan materi dalam pembelajaran. Dengan metode pembelajaran Kompetisi dan Aktifitas (Kompak) dapat mempercepat peningkatan mutu pendidikan melalui penyelenggaraan proses pembelajaran yang berkualitas. Dengan menggunakan Pembelajaran kompak diduga dapat meningkatkan keaktifan belajar peserta didik sehingga pembelajaran yang berlangsung akan lebih bermakna. Karena dengan menggunakan Pembelajaran kompak peserta didik akan aktif berkompetisi (Darsino, 2018).

Berdasarkan observasi yang dilaksanakan penulis, bahwa guru pada sekolah tersebut tidak menggunakan model pembelajaran Kompetisi dan Aktifitas (Kompak) karena guru tersebut belum mampu untuk menerapkannya dalam proses pembelajaran, dilain pihak ada guru yang masa bodoh dan tidak berat dengan tugas yang diembangnya yang menyebabkan rendahnya hasil belajar murid.

\section{Metode Penelitian}

Jenis penelitian ini adalah Penelitian Tindakan Kelas (PTK). Penelitian ini disusun untuk memecahkan suatu masalah, diujicobakan dalam situasi sebenarnya dengan melihat kekurangan dan kelebihan serta melakukan perubahan yang berfungsi sebagai peningkatan. Penelitian Tindakan Kelas merupakan suatu pencermatan terhadap kegiatan belajar berupa sebuah tindakan, yang sengaja dimunculkan dan terjadi dalam sebuah kelas secara bersama (Arikunto, 2007). Kemudian PTK merupakan penelitian yang dilakukan oleh guru di kelasnya sendiri dengan cara merencanakan, melaksanakan, dan merefleksikan tindakan secara kolaboratif dan partisipatif dengan tujuan memperbaiki kinerja guru sehingga hasil belajar siswa dapat meningkat (Kusumah \& Dwitagama, 2010). PTK sebagai proses pengkajian masalah pembelajaran di dalam kelas melalui refleksi diri dalam upaya untuk memecahkan 
masalah tersebut dengan cara melakukan berbagai tindakan yang terencana dalam situasi nyata serta menganalisis setiap pengaruh dari perlakuan tersebut (Sanjaya. 2011). Arikunto (2006) menjelaskan bahwa dalam penelitian kolaborasi, pihak yang melakukan tindakan adalah guru kelas itu sendiri sedangkan yang melakukan pengamatan terhadap berlangsungnya proses tindakan adalah peneliti. Penelitian tindakan kelas ini dilakukan dengan tujuan untuk meningkatkan hasil belajar siswa melalui Pembelajaran Matematika Realistik dalam pembelajaran Matematika. Penelitian tindakan kelas yang digunakan dalam penelitian ini mengacu pada Model Kemmis \& McTaggrat yang terdiri dari empat komponen, yaitu perencanaan (planning), tindakan (acting), pengamatan (observing) dan refleksi (reflecting).

Penelitian ini dilakukan di SMP Negeri 1 Maja Kabupaten Majalengka. Adapun yang menjadi subjek penelitian adalah Murid Kelas VIII D SMP Negeri 1 Maja Kabupaten Majalengka sebanyak 31 Orang murid. Penelitian dilakukan pada tahun 2019/2020. Penelitian ini menggunakan metode pengamatan (observasi), tes dan dokumentasi.

\section{Hasil dan Pembahasan}

Penulis melakukan penelitian pada pelaksanaan perbaikan pembelajaran sebanyak dua siklus yaitu siklus I dan siklus II. Penelitian pada masing-masing siklus mencakup penilaian aktivitas guru dan siswa selama pelaksanaan perbaikan pembelajaran dan penilaian hasil belajar siswa setelah selesai pelaksanaan perbaikan pembelajaran.

Hasil tes formatif dari 31 siswa Kelas VIII D SMP Negeri 1 Maja Kabupaten Majalengka dengan kompetensi Dasar "Memahami Teks Cerita Fabel" pra siklus, siklus I, siklus II dapat dilihat dari tabel I.

Tabel 1. Hasil Belajar siswa pada mata pelajaran Bahasa Indonesia

\begin{tabular}{clccc}
\hline No & \multicolumn{1}{c}{ Nama Siswa } & Pra Siklus & Siklus I & Siklus II \\
\hline 1 & Ade Muhammad Haikal & 40 & 50 & 80 \\
2 & Algufron Nazal Ramdani & 45 & 70 & 80 \\
3 & Andra Hasan Mutholib & 70 & 50 & 80 \\
4 & Deda & 70 & 70 & 85 \\
5 & Didi Wardi & 50 & 60 & 85 \\
6 & Dienfanzahry Rafi Musqie & 70 & 70 & 85 \\
7 & Fahmi Adam & 40 & 50 & 85 \\
8 & Faisal Ilhami Putra Rahayu & 70 & 70 & 85 \\
9 & Gio Anugrah & 55 & 65 & 90 \\
10 & Iamam Muhamad Maruf & 70 & 55 & 90 \\
11 & Iqbal Sabiq Maulana Muflih & 40 & 70 & 90 \\
12 & Ivan Roja Raharja & 50 & 60 & 90 \\
13 & Kiki Maulana & 70 & 70 & 90 \\
14 & M. Fikri Rahmatullah & 60 & 70 & 95 \\
15 & Maulana Fahreza Yusup & 60 & 70 & 95 \\
16 & M. Dzikri Sholahun Naqib & 70 & 60 & 85 \\
17 & M. Fajar Akbar Muzaky & 60 & 70 & 95 \\
\hline
\end{tabular}




\begin{tabular}{clccc}
\hline No Nama Siswa & Pra Siklus & Siklus I & Siklus II \\
\hline 18 & M Aditia Nurwahid & 55 & 65 & 90 \\
19 & M Adnan & 40 & 70 & 85 \\
20 & M Afrija Maulana & 70 & 60 & 85 \\
21 & M Abim Pebrian & 50 & 70 & 85 \\
22 & M Bily Ibrahim & 50 & 60 & 85 \\
23 & M Hilman Khoerusy Syah & 40 & 50 & 85 \\
24 & Nandi Ramdani & 70 & 70 & 85 \\
25 & Pandu Yassar Alfarros & 55 & 65 & 90 \\
26 & Rafli Ardani & 45 & 55 & 80 \\
27 & Retrial Modifa M & 40 & 70 & 85 \\
28 & Riyan Rohian Ramdhani & 50 & 60 & 85 \\
30 & Rizki Abdul Wahid & 50 & 70 & 85 \\
31 & Zaidan Fahrizal Arfan & 50 & 60 & 85 \\
& Jumlah & 1655 & 1905 & 2595 \\
& Rata - rata & 55,16 & 63,5 & 86,5 \\
\hline
\end{tabular}

Berdasarkan analisis hasil evaluasi yang telah dilaksanakan, sebelum adanya perbaikan pembelajaran (pra siklus) tercatat 22 siswa dari 31 siswa yang mendapat nilai kurang dari 70 dengan nilai terendah 40 dan nilai rata-rata 55,16. Namun setelah adanya perbaikan pembelajaran siklus I, siswa yang mencapai nilai 70 semakin bertambah yakni 15 siswa dengan rata-rata kelas 63.05 pada siklus II siswa yang mencapai nilai di atas 70 semakin bertambah dengan rata-rata kelas 86,5.

Grafik Prosentase Aktivitas Siswa Kelas VIII D SMP Negeri 1 Maja Kabupaten Majalengka Mata Pelajaran Bahasa Indonesia Pra Siklus, Siklus I, dan Siklus II

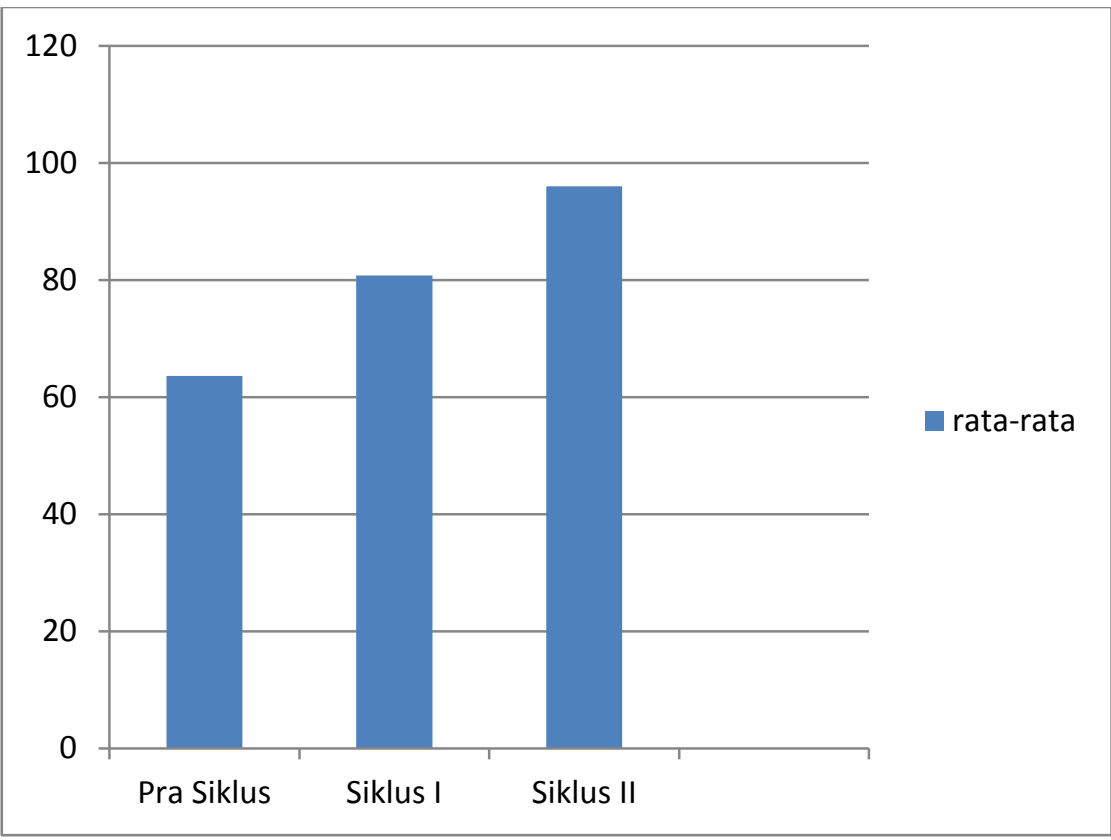

Gambar 1. Rata-rata keberhasilan siswa dalam melaksanakan pembelajaran KOMPAK 
Hasil refleksi terhadap hasil proses perbaikan pembelajaran dan hasil observasi yang dilakukan pengamat tercatat hal-hal sebagai berikut:

Sebelum diadakan perbaikan pembelajaran (pra siklus) Bahasa Indonesia, tingkat kegairahan dan keberanian siswa tergolong rendah yaitu hanya $77 \%$. Aktifitas pembelajaran masih didominasi oleh guru. Namun setelah perbaikan pembelajaran siklus I, kegairahan dan keberanian siswa dalam pembelajaran meningkat menjadi $86 \%$ siswa terlihat aktif dan antusias dalam pembelajaran, $80 \%$ siswa menjawab pertanyaan guru, $80 \%$ siswa bertanggung jawab terhadap tugas yang diberikan guru. Pada siklus II siswa aktivitas siswa semakin bertambah menjadi $95 \%$.

Pada siklus I, dari 31 siswa masih banyak siswa yang mendapatkan nilai dibawah KKM (KKM yang ditetapkan 70) dengan prosentase sebagai berikut 0-69 sebanyak 21 anak (68\%) dan 70-100 sebanyak 10 anak (32\%). Rendahnya prestasi belajar siswa pada pra siklus dikarenakan guru belum menggunakan metode pembelajaran yang tepat. Aktivitas belajar siswa masih tergolong rendah karena tingkat keaktifan siswa hanya 59\%. Rendahnya aktifitas siswa ini disebabkan karena guru belum menggunakan media pembelajaran yang tepat. Berdasarkan data hasil penelitian diperoleh bahwa pada mata pelajaran Bahasa Indonesia dari 31 siswa masih banyak juga siswa yang mendapatkan nilai dibawah KKM dengan prosentase sebagai berikut : 0-69 sebanyak 16 anak ( 52\%) dan 70-100 sebanyak 15 anak (48\%) Banyak siswa yang mendapatkan nilai dibawah KKM disebabkan karena guru kurang siap dalam menyampaikan pembelajaran walaupun sudah menggunakan metode yang tepat yaitu metode latihan.

Dalam hal aktivitas belajar, siswa banyak mengalami kemajuan dari $59 \%$ menjadi $74 \%$ hal ini dikarenakan guru sudah menggunakan media pembelajaran yang sudah tepat yaitu menggunakan media gambar atau foicture to ficture.

Pada siklus II, dari 31 siswa telah banyak siswa yang mendapatkan nilai diatas KKM dengan prosentase sebagai berikut : 0-69 tidak ada dan 70-100 sebanyak 31 anak (100\%), dalam hal ini pembelajaran dikatakan tuntas. Dalam hal aktifitas belajar, siswa banyak mengalami peningkatan yang signifikan yaitu dari pra siklus $59 \%$, siklus $74 \%$ sedangkan siklus II-nya $92 \%$.

\section{Simpulan}

Berdasarkan hasil penelitian yang telah dilaksanakan, maka dapat disimpulkan bahwa hasil belajar siswa melalui Metode Pembelajaran Kompak mengalami peningkatan. dapat disimpulkan metode kompetisi dan aktivitas dapat meningkatkan hasil belajar siswa pada mata pelajaran Bahasa Indonesia.

\section{Daftar Pustaka}

Arikunto. (2006). Prosedur Penelitian Suatu Pendekatan Praktik. Jakarta: Rineka Cipta.

Arikunto. (2007). Penelitian Tindakan Kelas. Jakarta: Bumi Aksara.

Ayuningrum, S. (2017). Peningkatan Hasil Belajar Bahasa Indonesia Pada Aspek Keterampilan Berbahasa Melalui Model Pembelajaran Kreatif Produktif di SMK Islam PB. Soedirman 1. Jurnal Visipena, 8 (2), 351-372. 
Darsino. (2018). Pembelajaran Kooperatif Model Kompak Untuk Meningkatkan Keaktifan dan Hasil Belajar PKn Peserta Didik Kelas VI SDN Gebangsari 02. Jurnal Ilmiah "Pendidikan Dasar", 5(1), 57-66.

Kurniawan, H. (2015). Pemebelajaran Kreatif Kurikulum 2013. Jakarta: Prenada Group.

Kusumah \& Dwitagama. (2010). Mengenal penelitian Tindakan Kelas. Jakarta: PT Indeks.

Rohmanurmeta, FM. (2017). Peningkatan Hasil Belajar Bahasa Indonesia Melalui Metode Role Playing Pada Siswa Sekolah Dasar. Bahastra, 37(1), 24-31.

Sanjaya. (2011). Penelitian Tindakan Kelas. Jakarta: Kencana.

Sugiyono. (2014). Meningkatkan Hasil Belajar Bahasa Indonesia Materi Melaporkan Isi Buku Melalui Pendekatan Komunikatif Metode SQ2R Pada Siswa Kelas 6 SDN Kramat Sukoharjo 03 Jember. Pancaran, 3(3), hal 123-134.

Sukmadinata, NS. (2004). Landasan Psikologi Proses Pendidikan. Bandung: PT remaja Rosdakarya 